\title{
ANATOMIA DE ANDRÉ GIDE
}

\section{Luis Martins}

Em 1973, em Paris, eu me hospedei no Hotel Bedford, muito conhecido dos brasileiros, porque nele morreu o Imperador Pedro II. Foi aí que tive com Roger Bastide o derradeiro encontro, numa conversa de quase duas horas, no bar. E foi nessa ocasião que ele me ofereceu um exemplar do seu livro "Anatomie d'André Gide", "en souvenir de notre rencontre a Paris, un froid printemps de 1973, bien amicalement". Nunca mais o vi. Depois disso, ele esteve rapidamente no Brasil, mas, devido a certas circunstâncias que então me atribulavam, não tive ocasião de procurá-lo. Por isto, lembro-me de Bastide assim - e me é grato lembrar: pela última vez em Paris, em cumprimento a um encontro marcado alguns anos antes, que o destino retardara, mas acabara por tornar possível.

"Anatomie d'André Gide". Tenho a impressão de que esse livrinho de 171 páginas, editado em formato elegante pelas "Presses Universitaires de France" (1972), é bem pouco conhecido no Brasil. E, aqui entre nós, falando com franqueza, o próprio Gide o será mais? Mesmo nos meios intelectuais (há exceçð̃es, sem dúvida), o que nele impressiona e logo se torna tema das discussð̃es, é o homossexual, ou o apóstolo da pederastia, como se toda a sua obra literária fosse uma projeção dessa inclinação sexual, por ele próprio admitida, divulgada e heroicamente defendida.

Certamente, ela tem importância e deve ser levada em conta, pois não se poderia negar a influência que exerceu na transformação da personalidade do escritor e, portanto, em sua obra, tão intimamente ligada à sua vida. Esse estudo já foi feito, de forma magistral pelo Dr. Jean Delay, nos dois alentados volumes que tềm como título "La Jeunesse d'André Gide". Mas Delay é psicanalista e a psicanálise não pode prescindir da biografia. $\mathbf{O}$ enfoque de Roger Bastide é outro. A palavra "anatomia", no título do livro, poderia .evar um leitor desprevenido a incorrer em equívoco, mas no fundo, é precisamente disso que se trata; uma dissecação da obra gideana, considerada como um corpo vivo, para daí tentar-se a ińterpretação psicológica do homem que a criou. Não é uma crítica literária, entretanto. Nisto, Bastide não atendeu o apelo de Gide, quando no fim da vida reclamava para o julgamento de sua obra um ponto de vista exclusivamente estético, o único que julgava pertinente e válido. A rigor, o que Bastide analisa (ou disseca) 
é aquela "moral da ambiguidade", que seria a marca registrada de Gide - mas para refutá-la, da maneira mais lúcida e inteligente possível.

O imoralismo gideano não é um amoralismo. Ou, especificando melhor, com palavras do próprio Roger Bastide: para o autor do "Corydon", "ce qui est important, ce n'est pas le contenu matérial de la regle morale que l'on se donne, mais c'est d'avoir une regle".

O grande escritor sempre deu a seus críticos a impressão de um ser sinuoso e perpetuamente infiel a si mesmo. A primeira vista, parece incompreensível que o místico dos "Cahiers d'Andre Walter" e do "Numquid et tu...? possa ter escrito as "Nourritures Terrestres", cântico pagão, ou as terríveis confissões do "Si le grain ne meurt". Que o criador da Alissa de "La Porte Étroite" seja o mesmo do Lafcadio das "Cafes du Vatican".

Entretanto, essa constante contradição, essa aparente incoerencia, essa flagrante oposição a si mesmo, que pareciam manifestar-se violentamente na sucessão dos livros publicados, não eram uma exibição de cinismo, ou uma forma de confundir o leitor.

Significavam, ao contrário, em Gide; uma dramática procura da própria identidade. Como observava Bastide, na esteira da maioria dos críticos que se ocuparam da obra gideana, os seus personagens não passam de imagens, exteriores, de si mesmo; não são criações autônomas do romancista. Gide é, ao mesmo tempo, Edouard e Georges, Lafcadio e Fleurissoire. Trata-se, em verdade, não de uma incapacidade ou impotência criadora, mas de uma nova tática para iluminar as trevas do caos interior, dividindo-as em tantas parcelas quantas necessárias para melhor elucidá-las; em outras palavras, transformar os rumores selvagens "du dedans" em vozes que dialogam. Porque, como o próprio Gide confessa: "Eu sou mil possíveis em mim; mas não posso me resignar a não querer ser mais que um." Daí resulta o homem-labiríntico. (O labirinto onde se perdem os criticos, mas não Teseu - leia-se: Gide - que dele poderá sair, uma vez que está ligado a Ariana por um fio).

Todavia, não é essa imagem arquitetural (o labirinto) que Bastide preferiria reter para melhor reduzir a verdadeira natureza da obra de Gide, mas outra mais significativa, fornecida pela música. Com efeito, essa obra nada mais é que uma vasta partitura musical, visto que a música é certamente criação de temas, mas de temas que não se cristalizam, que incessantemente se transformam em outros, continuando, não obstante, sempre os mesmos. As aparentes dissonâncias se sucedem no tempo, mas como variações sonoras do mesmo leitmotiv.

Assim se reconciliam a discontinuidade - cada frase musical tendo sua autonomia e seu sentido interno - e a continuidade, que nos faz passar insensivelmente de uma a outra fase, dando por isto mesmo a cada uma delas uma significação diferente de sua significação interna; ou seja, um sentido que vem do contexto em que ela se encontra. 
Bastide observa que no "Teseu", um dos últimos livros escritos por Gide, reencontram-se, recuperados, todos os temas de suas obras anteriores. Agora simultâneos, em vez de sucessivos. Antes, os livros que se sucediam, aparentemente antagônicos e contraditórios, eram na verdade como responsos de uma mesma frase musical, que sempre reaparece, obsessivamente.

Poder-se-ia dizer, portanto, que toda essa desconcertante mobilidade não atua desordenadamente, no vácuo; ela tem uma direção precisa, um rumo coerente e premeditado. A conclusão é que cada um dos livros de Gide não pode ser isolado dos outros, pois todos eles constituem momentos sucessivos de uma vasta sinfonia. A sucessã̃o não é mais que a procura da própria identidade; e na multiplicidade dos personagens, devemos ver a revelação progressiva do ser, pelo desdobramento de sua unidade.

É claro, é óbvio, é evidente que não alimento a menor pretensão de estar dando ao leitor sequer uma pálida, superficial e resumida idéia do que é o importante livro de Roger Bastide. Eu não seria capaz dessa proeza, entre muitas outras razס̃es, por uma questão de espaço. Gostaria apenas de acrescentar ao que foi dito acima, algumas poucas linhas, por conta própria.

André Gide talvez tenha levado ao extremo - para embaraço e perplexidade de seus críticos - a representação do homem labiríntico, na complexidade de sua obra literária. Mas, na verdade, todos nós não somos mais ou menos assim? A contradição é própria da natureza humana, porque, como disse Sérgio Milliet num de seus melhores versos, "jamais seremos um mais que um minuto". 0 homem é um ser múltiplo e incessantemente mutável, no tempo e no espaço. Se Gide se sentia "mil possíveis", o nosso Mário de Andrade, um pouco mais parcimonioso, contentava-se em ser "trezentos, trezentos e cinquenta".

A inquietação gideana, levada aos últimos limites, é uma tentativa de libertação. 0 drama crucial do homem é a limitação da sua própria condição, im. posta pelos deuses. 0 mito de Prometeu encadeado ño tem outra significação: ele só se libertará se matar a águia que o devora. E, sendo livre, será igual aos deuses.

$\mathrm{Na}$ análise demorada e profunda que faz do ato gratuito - a mais famosa invenção de Gide - mestre Bastide discorda, em parte, de Léon Pierre-Quint, que o assimilara ao ato livre, de Bergson. Não obstante, reconhece que pelo ato gratuito o indivíduo eleva-se acima da condição humana, tornando-se assim um rival dos deuses, ou ele próprio também um deus. Lafcadio é o sucessor de Źeus.

Em dezembro de 1975, a Dra. Maria Isaura Pereira de Queiroz, diretora científica do Centro de Estudos Rurais e Urbanos, teve a bondade de me convidar a participar de uma mesa-redonda na "Semana Roger Bastide", programada para maio de 1976, por aquela entidade, juntamente com o Instituto de Estudos Brasileiros e o Departamento de Ciencias Socias da USP. 
Infelizmente, por motivos de ordem pessoal, não me foi possi vel participar desse justíssimo empreendimento. Posteriormente, a Dra. Maria Isaura ainda convidou-me a escrever algumas linhas sobre Bastide, para um volume que o mesmo Centro pretendia editar, em homenagem a esse grande amigo do Brasil, que também me honrava com a sua amizade. E, pela segunda vez, vi-me na contigência de não poder corresponder a tamanha gentileza. Minha vida, na ocasião, andava muito atrapalhada.

O presente artigo destina-se, em parte, a reparar essa omissão. É o meu pequeno e tardio preito de admiração, de amizade e de saudade ao mestre ilustre. Ele não tem outro mérito - quero deixar isso bem claro - que o de lembrar aos brasileiros um livro que nem todos conhecem: o último que Roger Bastide escreveu ou, pelo menos, que foi editado antes de sua morte. 